\title{
LA POESIA CÓSMICA DE MATTEO BONSANTE
}

\author{
Carmelo Vera Saura \\ Universidad de Sevilla
}

Hay poetas que pasan desapercibidos por la escena de la literatura, que desde hace tiempo, está sujeta al mercado y a la publicidad. Si hablamos de poesía sabemos de lo desconocidos y secretos que son algunos poetas que no han encontrado un editor atento a la poesía y no al mercado. Tal es el caso de Matteo Bonsante, que ha recogido la poesía de toda una vida, publicada e inédita, Poesie, 1954-2004, Polignano al Mare (Bari), Aliante, 2004. Sus tres grandes libros son Bilico (1986), Ziqqurat (1996) y Sigizie (1998)

Nos encontramos ante una poesía pura, pulida, en continua búsqueda de una profundidad del ser humano, que, para Bonsante, tiene algo de divino o, al menos, está en contacto con una zona numinosa que lo acerca a la divinidad, a una fuerza que sobrepasa al hombre y que mitifica todo evento o paisaje en una dimensión cósmica. Su forma poética querría nombrar un mundo recién creado como si fuese la palabra primigenia que creara el mundo con sus palabras (algo hay de ello en el poema Sulle terrazze del dio), que, en el fondo, es el sueño de todo poeta, y que nos recuerda a la poesía de Ungaretti. Pero existe también la imposibilidad de llegar a una verdad (Con rumore di foglie). Preciosas son las imágenes metafóricas utilizadas (el mar como escarabajo de oro, el sol como rueda de molino, la hostia lunar, la leche de murciélago, el ojo del rapaz, etc.). El paisaje mediterráneo, muy similar al del sur de España, aparece constantemente suspendido en el tiempo, con sus algarrobos, sus almendros, sus chumberas, etc. La búsqueda de lo ultramundano es también búsqueda de dios, hostia lunar, microcosmos y macrocosmos, en la última parte de Bilico. Ziqqurat quiere ser aún más desnudo, más espiritual y minimalista en la expresión. La maravilla de vivir y de sentir que se vive están acompañados por las dudas. Pero vence siempre el yo en el todo, los elementos arquetípicos, la naturaleza filosófica del poema. Es esta una poesía con grandes dosis de platonismo en sentido filosófico y no negativo, al ver este mundo como un reflejo del otro (¿fe o filosofía?) mundo inefable. En este sentido, es un mundo opuesto al de Leopardi, para quien después de esta vida terrestre sólo existe la nada, y la naturaleza, madrastra y malvada, no tiene piedad del hombre. Quizá comparte con el poeta recanatés la idea de la poesía como lugar de lo sublime y de la infinitud del mundo. Bonsante es cercano a Leopardi en las imágenes, pero no en la visión ideológica del mundo.

Bajo la naturaleza metafísica de la poesía de Bonsante existe una naturaleza metapoética, de reflexión sobre la misma naturaleza de la poesía, del poeta, de la 
escritura: $<<$ Cerco parole capaci/di sostituirmi $>>$, que responde a ese ansia de vivir en las palabras, en la pura vida, en el soplo de un dios que anima el mondo, donde el yo se anula, y en este sentido, es una poesía mística. El yo alcanza la plenitud (la mayor parte de las veces) en el mismo momento en el que alcanza el vacío. Habría que ver cuánto hay de cultura arquetípica y de ultratumba, como en ese poema en el que quiere expresar la transmigración de las almas (In qualche parte remota, Ziqqurat).

Sigizie comprende una serie de poemas de amor, que, como en los anteriores, ve y siente a la amada en cada elemento de la naturaleza, casi como una diosa inalcanzable, como ese dios de los poemarios anteriores. Oscilante entre el eros del bíblico Cantar de los cantares o la poesía amorosa de Sandro Penna, Bonsante elabora una poesía pura y ahora más humana, escoge una palabra siempre controlada y selectiva, e, icluso en los poemas más eróticos $(<<$ Ho scavato nel tuo corpo/come l'acqua scava immemore/nella rocía viva $>>$ ), la corporeidad desaparece a merced de elementos arquetípicos como el agua, la roca, o la anulación del tiempo.

Hay que destacar el esfuerzo del poeta por ser comprendido por el lector al poner al final de cada poema unas notas explicativas, a veces más largas que el mismo poema, que son un ejercicio de claridad que ayuda al lector a entender y gozar estos poemas, y nunca les resta poeticidad. Yo siempre he deseado que los poetas explicasen sus poemas, que dictaran en lenguaje transparente su metaforismo y su visión del mundo. Cercana al haikù y a la greguería (en las metáforas e imágenes deslumbrantes) de nuestro Ramón Gómez de la Serna, pero siempre metafísica e arquetípica, la poesía de Matteo Bonsante brota de una palabra contenida y henchida, austera y bella, ajena a la historia, numinosa. 